Georgetown University Law Center

Scholarship @ GEORGETOWN LAW

2013

\title{
Construction and Constraint: Discussion of Living Originalism
}

Lawrence B. Solum

Georgetown University Law Center, Ibs32@law.georgetown.edu

This paper can be downloaded free of charge from:

https://scholarship.law.georgetown.edu/facpub/1351

7 Jerusalem Rev. Legal Stud. 17-34 (2013)

This open-access article is brought to you by the Georgetown Law Library. Posted with permission of the author. Follow this and additional works at: https://scholarship.law.georgetown.edu/facpub

Part of the Constitutional Law Commons, Legal History Commons, and the Legal Theory Commons 


\title{
Construction and Constraint: Discussion of Living Originalism
}

\author{
Lawrence B. Solum ${ }^{\star}$
}

\section{Introduction: Living Originalism and the problem of constraint}

Jack Balkin's Living Originalism ${ }^{1}$ raises many important questions about contemporary constitutional theory. Can and should liberals and progressives embrace originalism? Can the New Deal expansion of national legislative power be given originalist foundations? Is there a plausible originalist case for a right to reproductive autonomy and hence for the Court's decision in Roe v. Wade? ${ }^{2}$ Is the fact of theoretical disagreement among originalists evidence for the thesis that the originalist project is in disarray?

On important issue raised by Balkin's version of originalism is connected with debates about the role of courts and judges in constitutional adjudication. The US Supreme Court has the final say on constitutional questions. The US Constitution contains a variety of broadly worded abstract provisions, including the First Amendment recognition of a right of "freedom of speech" and Article Two's vesting of "executive power" in the President. Living constitutionalismthe view that the meaning of the Constitution should adapt to changing circumstances and values-seems to provide the Justices with unconstrained power to shape constitutional law in the image of their personal views about policy and morality. Unlike the Congress and the President, the Supreme Court is only weakly constrained by democratic elections, separation of powers, and checks and balances. Supreme Court Justices have life terms. The decisions of the Supreme Court on constitutional questions cannot be vetoed by the President or modified by ordinary legislation. Of course some checks are available. The Constitution can be amended. Justices can be impeached. In theory, the number of Justices can be expanded through ordinary legislation. More controversially, Congress may have the power to constrain the court by modifying its jurisdiction. These checks provide some constraint, but

\footnotetext{
* John Carroll Research Professor of Law, Georgetown Law Center. Email: Isolum@gmail.com

1 Jack Balkin, Luing Originalism (2011).

2410 U.S. 113 (1973).
} 
critics of the Court's constitutional jurisprudence worry about their sufficiency. Let us call the worry articulated by these critics "the problem of constraint."

Early versions of constitutional originalism addressed the problem of constraint. The Supreme Court could bind itself. Justices would decide constitutional cases in accord with the original meaning of the constitutional text or the original intentions of the framers. Constrained by original meaning, the Justices would no longer be free to impose their own views about controversial issues in the guise of constitutional interpretation.

But early versions of originalism were criticized. Indeed, the term "originalism" was coined by Paul Brest in an article entitled The Misconceived Quest for the Original Understanding. ${ }^{3}$ Brest and others raised a host of objections to the idea that the framer's intentions could provide a determine guide for the resolution of constitutional controversies. The nascent originalist camp responded to the criticisms in various ways, but a crucial move occurred in 1986, when Justice Scalia gave a speech exhorting originalists to "change the label from the Doctrine of Original Intent to the Doctrine of Original Meaning."4 The phrase "original public meaning" entered contemporary theoretical debates through the work of Gary Lawson, ${ }^{5}$ and subsequently in work by Steven Calabresi and Sai Prakash. ${ }^{6}$ More work on what came to be called "the New Originalism" or "Original Public Meaning Originalism" was done by Randy Barnett ${ }^{7}$ and Keith Whittington. ${ }^{8}$ At this stage in the evolution of originalist constitutional theory, the theory was associated with scholars and judges who could be characterized as conservative or libertarian. Living constitutionalists and the critics of originalism tended to be liberal or progressive.

This very compressed story of the evolution of originalist theory ${ }^{9}$ sets the stage for Jack Balkin's Living Originalism. Balkin advocates "framework originalism"a form of originalism that attempts to reconcile fidelity to the original meaning of the Constitution with the very doctrines of constitutional law that gave rise to conservative worries about the problem of constraint. Living Originalism endorses the outcomes of New Deal cases that expand federal power and Warren and Burger Court cases that recognize unenumerated rights to privacy and reproductive autonomy. Does Balkin have a solution to the problem of constraint? Or

\footnotetext{
${ }^{3}$ Paul Brest, The Misconceived Quest for the Original Understanding, 60 B.U.L. Rev. 204, 234 (1980).

${ }^{4}$ Antonin Scalia, Address Before the Attorney General's Conference on Economic Liberties in Washington, D.C. (14 June 1986), in Original MEaning JuRisprudence: A Sourcebook 101 at 106 (US Department of Justice ed. 1987).

${ }^{5}$ See Gary Lawson, Proving the Law, 86 Nw. U. L. Rev. 859 at 875 (1992).

6 See Steven G. Calabresi \& Saikrishna B. Prakash, The President's Power to Execute the Laws, 104 Yale L. J. 541 at 553 (1994).

7 See Randy E. Barnett, Restoring the Lost Constitution (2004).

${ }^{8}$ See Kerth E. Whittington, Constitutional Construction (1999); Keith E. Whittington, CONSTITUTIONAL INTERPRETATION (1999).

${ }^{9}$ For a less compressed version of the story, see Lawrence B. Solum, What Is Originalism? The Evolution of Contemporary Originalist Theory, in THE CHALLENGE OF ORIGNALISM: Theories OF CoNstTtutional. INterpretation 12, 33 (Grant Huscroft \& Bradley W. Miller eds., 2011) [hereinafter, Solum, What is Originalism?].
} 
is Living Originalism an attempt to reformulate originalist theory in a way that legitimizes a relative unconstrained practice of judicial review?

Some critics of contemporary originalist theory argue that efforts like Balkin's are inconsistent with the spirit of the originalist project. Consider the following passage from an essay by Martin H. Redish and Matthew B. Arnould:

Recall that originalism grew out of an understandable desire to cabin the interpretive discretion of unrepresentative, unaccountable judges who, under the guise of "interpreting" the counter-majoritarian Constitution, were all too often trumping the democratic process by superimposing their own social policy choices on the majoritarian political process. The means for restraining modern judicial review contemplated by originalist theory was to confine the interpretive options open to modern judges to the understandings of those alive at the time of the framing and ratification of the relevant constitutional provision. Yet, contrary to this asserted goal, the originalist construction school openly concedes the widespread impossibility of successfully performing the archaeological and translational task that is the sine qua non of true originalist analysis. It replaces it with an indeterminate mode of "construction" that permits the very results that originalism was designed to avoid-namely, the unrestrained judicial trumping of democratically authorized decision making and the implementation of textual understandings of which those alive at the time of ratification would have been totally unaware. This may well be an appropriate means of constitutional construction for those of us who have long categorically rejected the entire originalist endeavor as hopeless and often manipulative. But it is surely Orwellian to describe this theory as "originalist" in any meaningful sense of that term. ${ }^{10}$

The remainder of this essay tackles these questions, beginning in section "The core of originalist constitutional theory", which examines the theoretical structure of the problem of constraint in the context of originalist theory. Section "The interpretation-construction distinction" examines Balkin's approach to the problem of constraint in two ways, first by examining the theoretical structure of framework originalism and second by looking closely at Balkin's discussion of national legislative power. Section "The mechanisms of constraint" concludes.

Our aim at this stage is to understand the problem of constraint in the context of originalist constitutional theory. We can begin with a brief investigation of originalism itself.

\section{The core of originalist constitutional theory}

Originalism is a family of theories. We have already seen two prominent members of the family, "original intentions originalism" and "original public

${ }^{10}$ Martin H. Redish \& Matthew B. Arnould, fudicial Review, Constitutional Interpretation, and the Democratic Dilemma: Proposing a "Controlled Activism" Alternative, 64 FL. L. Rev. 1485, 1509 (2012). Redish and Arnould do not provide a precise understanding of their notion of idea of construction, but they are not using the term in the same way that it is articulated by contemporary originalist theory. See Lawrence B. Solum, The Interpretation-Construction Distinction, 27 CoNist. Comment. 95 (2010). 
meaning originalism," but there are others, including a version of originalism that focuses on the understandings of the ratifiers and a variant of public-meaning originalism that emphasizes the original methods of constitutional interpretation. ${ }^{11}$ For our purposes, the important task is to identify the core ideas that these closely related versions of originalism share.

We can begin with a very basic distinction from general legal theory-the distinction between communicative content and legal content. This distinction could be stated using different language-we could differentiate between the "meaning of the constitutional text" and the "doctrines of constitutional law." The basic idea of the distinction is very simple. Legal texts have what we might call "linguistic meaning"- the meaning of the words and phrases in context. We can call this meaning the "communicative content" of the text. The communicative content of a text predates its adoption; indeed, we need to figure out what a legal text means in order to decide whether we should adopt it. But once a legal text is adopted, it gives rise to legal rules and these rules are not necessarily identical to the communicative content of the text. The constitution provides many examples of this distinction. The communicative content of the first amendment freedom of speech is roughly the linguistic meaning of these words: "Congress shall make no law ... abridging the freedom of speech." The linguistic meaning is quite sparse-containing only three basic elements: (i) a reference to the United States Congress; (ii) the idea of a prohibited abridgement; and (iii) the notion of "the freedom of speech." But the content of the associated doctrines of constitutional law is very rich indeed, including notions such as prior restraint, content-neutral time, place, and manner restrictions, and doctrines elaborating specific rules applying to public fora, the Internet, and even billboards. These doctrines of constitutional law provide the "legal content" of the First Amendment freedom of speech. It is clear that the two are not identical: the linguistic meaning of the words does not contain the elaborate structure of free-speech doctrine.

The distinction between communicative content and legal content gives us a vocabulary for a relatively precise articulation of the core of the family of originalist constitutional theories. The core consists of two principles, which we can call "the fixation thesis" and "the constraint principle."

The fixation thesis can be stated as follows:

The communicative content of the constitution (the linguistic meaning of the words in context) is fixed at the time each constitutional provision is framed and ratified.

This is a simple idea and it applies very generally to oral and written communication. It has two constituent elements, which we can call the "semantic component" and the "contextual component." The semantic component is

\footnotetext{
" John McGinnis \& Michael Rappaport, Original Methods Originalism: A New Theory of Interpretation and the Case Against Construction, 103 Nw. U. L. Rev. 751 (2009) [hereinafter Original Methods Originalism].
} 
based on the fact that conventional semantic meanings and the regularities we sometimes call rules of syntax and grammar are time bound:

The semantic content of constitutional meaning is fixed by linguistic practices at the time each constitutional provision is framed and ratified.

The semantic component of the fixation thesis is illustrated by the now-familiar example of the phrase "domestic violence" in Article IV of the US Constitution. Today, this phrase is mostly used to refer to violence within a family or household-spousal abuse, child abuse, and elder abuse, for example. But at the time Article IV was written, "domestic Violence" referred to riots, rebellions, and other forms of harmful physical force within the territory of a political unit-in context, within the boundaries of a state. ${ }^{12}$ The phrase domestic violence illustrates the well-known phenomenon of linguistic drift-the gradual change of linguistic meanings over time. ${ }^{13}$

The second aspect of the fixation thesis goes to the contribution of context to communicative content. The context in which a text is communicated to a reader is fixed in time. This contextual component of the fixation thesis can be stated as follows:

The publicly available context of constitutional communication is fixed at the time the text was framed and ratified.

In the case of the various provisions of the US Constitution, the context is fixed at the time each provision was framed and rectified, but it includes the entire publicly shared context. For example, the context in which the Constitution of 1789 was framed and ratified includes the events surrounding the Philadelphia Convention, but it also includes experience under the Articles of Confederation, the American Revolution, and likely important events in English constitutional history (e.g., Magna Carta). Amendments to the Constitution are proposed and ratified at a particular time, but the relevant context shared by drafters, the participants in proposal and ratification, and the public may include events from past years or decades. ${ }^{14}$

The fixation thesis is the first element of the core of contemporary originalism. The second element is the constraint principle. The idea of the constraint principle is simple and highly intuitive:

The communicative content of the constitutional text should constrain the content of constitutional doctrine.

12 See Balkin, supra note 1 at 37 . For a contrary, clever, and utterly implausible argument to the contrary, see Mark S. Stein, The Domestic Violence Clause in "New Originalist" Theory, 37 Hastings Const. L. Q. 129, 133-35 (2009).

13 Sol Stenmetz, Semantic Antics: How and Why Words Change Meaning (2008).

14 The Twenty-Seventh Amendment to the Constitution is a special case; it was proposed by Congress on 25 September 1789, but ratification did not occur until 7 May 1992. See Certification of Amendment to the Constitution of the United States Relating to Compensation of Members of Congress, 57 Fed. Reg. 21, 18788 (19 May 1992). 
The constraint principle expresses the originalist solution to the problem of constraint. Even living constitutionalists are likely to believe that the original meaning of the constitutional text should play some role in constitutional interpretation and construction. What makes the originalist family of constitutional theories distinctive is commitment to the constraint principle.

The statement of the constraint principle upon which all or almost all originalist theories converge is abstract and vague. Some originalists may endorse versions of the principle that provide very strong constraint; others may accept weaker forms of constraint. We can illustrate variations in the constraint principle by articulating both a minimalist and a maximalist version.

At a minimum, originalists could believe that the legal content of constitutional doctrine must satisfy two requirements. First, constitutional doctrine may not be inconsistent with the linguistic meaning of the text in context. Second, the rules of constitutional law must include rules that fairly capture the communicative content of all of the portions of the text that are in force (not repealed). This minimalist version of the constraint principle would allow for constitutional doctrine that supplements the text in various ways-implementing rules (like the prior restraint doctrine in free-speech doctrine) are allowed.

At the maximum, originalists could believe that the legal content of constitutional doctrine must be identical to the linguistic meaning of the text in context. For the maximalist, each and every rule of constitutional law should be fairly traceable to the communicative content of the text. The doctrine of prior restraint would therefore be illegitimate unless was part of the semantic meaning of "freedom of speech" or communicated by First Amendment in context-by implication, implicature, impliciture, or some other form of contextual enrichment of semantic content.

The fixation thesis and the constraint principle constitute the core of contemporary originalist thought. These are the ideas upon which almost all originalists agree. Is framework originalist, the theory that Balkin advances in Living Originalism, consistent with the core? Balkin endorses the fixation thesis explicitly: "All forms of originalism claim that something is fixed in place at the time of adoption, that it cannot be altered except through amendment, that it matters for correct interpretation." 15 Similarly, framework originalism endorses a minimalist version of the constraint principle (and rejects a maximalist version associated with the theory that Balkin calls "skyscraper originalism."):

In skyscraper originalism, judges are constrained when they apply the original constitutional bargain using the proper methodology for ascertaining it; when they fail to do this, they are unconstrained and are simply imposing their own beliefs. Thus skyscraper originalism views following correct interpretive methodology as the central

\footnotetext{
15 Jack M. Balkin, Construtional Redemption: Polmtical. Fatth an an UnJust World 228 (2011) [hereinafter Constitutional Redemption].
} 
constraint of judges. Framework originalism also requires that judges apply the Constitution's original meaning. But it assumes that this will not be sufficient to decide a wised range of controversies so judges will have to engage in considerable constitutional construction as well as the elaboration and application of previous constructions. Hence, fidelity to original meaning cannot constrain judicial behavior all by itself. ${ }^{16}$

Thus, Balkin endorses both the fixation thesis and a version of the constraint principle. It follows that framework originalism is a member of the originalist family.

\section{The interpretation-construction distinction}

The core of contemporary originalism is defined by the fixation thesis and the constraint principle - the ideas upon which almost all contemporary originalists agree. Another important idea is more controversial-the interpretation-construction distinction. ${ }^{17}$ This distinction marks the difference between two different moments or activities. The first activity is the discovery of the communicative content (or linguistic meaning in context) of a legal utterance: I will use the term interpretation to name this activity. The second activity is the determination of the legal content and legal effect produced by a legal text: I will use the term construction to name this second and distinct activity. The interpretation-construction is an old one in American legal theory, ${ }^{18}$ and it has been much discussed recently in constitutional theory, but the words "interpretation" and "construction" are also used in a broader sense to refer to both activities (discovering meaning and determining legal effect). Nothing hangs on the terminology, since we could describe the interpretation-construction distinction using other words.

We can rationally reconstruct interpretation and construction as two moments in a larger activity, which we can call "constitutional practice." We could reconstruct this practice as involving two steps: first, we ascertain the communicative content of the constitutional text (interpretation), and second, we determine the legal effect of the text (construction). In judicial constitutional practice, this second step frequently involves "constitutional doctrine"elaborations of the legal content associated with the text. This rational reconstruction pictures interpretation and construction as two distinct steps performed in sequential order, but in actual constitutional practice, the two steps may be not be clearly distinguished and the sequence of reasoning may

\footnotetext{
${ }^{16}$ Balkin, supra note 1 at 22 .

17 Lawrence B. Solum, The Interpretation-Construction Distinction, 27 CoNst. Comment. 95 (2010).

${ }^{18}$ Francis Lieber, Legal and Poltical Hermeneutics (Roy M. Mersky \& J. Myron Jacobstein eds., Wm. S. Hein \& Co. 1970) (1839). For the Google Books version, see http://books.google.com/books?id=_ww AAAAAYAAJ\&dq=lieber+interpretation+construction\&source=gbs_navlinks_s.
} 
go from construction to interpretation and then back to construction (or in any other order).

How is the interpretation-construction related to the problem of constraint? In Living Originalism, Balkin explicitly endorses the interpretation-construction distinction and notes the important connection of construction to constraint.

Framework originalism also requires that judges apply the Constitution's original meaning. But it assumes that this will not be sufficient to decide a wised range of controversies so judges will have to engage in considerable constitutional construction as well as the elaboration and application of previous constructions. Hence, fidelity to original meaning cannot constrain judicial behavior all by itself. ${ }^{19}$

The claim that interpretation does not suffice to constraint constitutional practice is controversial among originalists.

Why is constitutional construction controversial? Constitutional practice necessarily involves both interpretation and construction. Construction (as defined) just is the activity of determining the effect to be given to the constitutional text. This happens whenever a constitutional case is decided or officials act on the basis of their constitutional understandings. The idea of constitutional construction becomes controversial when we introduce the claim that the communicative content of the constitutional text underdetermines the legal content of constitutional doctrine.

Why do some originalists (including Jack Balkin) believe that the linguistic meaning of the constitution does not answer all the questions that arise in constitutional practice? One answer to this question is provided by examples. Consider the free-speech clause (discussed above). Free-speech cases arise in particular circumstances; claims arise in the context of government regulations of campaign finance, billboards, commercial advertising, subversive speech, and so on. To many originalists, it seems obvious that the language of the First Amendment does not dictate the content of the constitutional doctrines required to resolve these cases. A second answer to the question provides a typology of the mechanisms of underdetermination. Consider four mechanisms: (i) irreducible ambiguity, (ii) vagueness or open texture, (iii) gaps or incompleteness, and (iv) contradictions or inconsistencies.

Ambiguity occurs when a legal text can have more than one meaning. In many cases, ambiguity can be resolved by reference to context, but there may be cases when ambiguity is irreducible. For example, the drafters of a legal text might introduce deliberate ambiguity in order to "paper over" a failure to agree on substance, "kicking the can down the road." If the ambiguity is truly irreducible, then the application of the text to a problem implicating the ambiguity cannot be resolved by interpretation-the ambiguous meaning underdetermines resolution of the problem.

\footnotetext{
${ }^{19}$ Balkin, supra note 1 at 22 .
} 
Vagueness arises when a term or expression involves borderline cases. For example, the Constitution of the USA uses the phrases "legislative power," "executive power," and "judicial power." It may be the case that the linguistic meaning of these phrases does not create sharp boundaries and bright lines: there may be borderline cases such that a particular action might be either legislative or executive in nature. (Think about an executive order creating a general practice not to deport undocumented persons who entered the country as children and who are currently enrolled as students.) Vague texts underdetermine the outcome of cases in the penumbra or on the borderline. Similar points can be made about gaps and contradictions. In some possible cases, an incomplete or inconsistent legal text will not provide communicative content sufficient to resolve a particular legal problem within the domain governed by the text.

Balkin's theory, framework originalism, is based on the assumption that the communicative content of legal texts underdetermines constitutional practice. For Balkin, much of the work of constitutional practice occurs in what we can call "the construction zone"-the area in which the linguistic meaning of the text is insufficient to provide determinate answers to constitutional questions. Constitutional construction can liquidate irreducible ambiguities, precisify vagueness, fill in gaps, and resolve contradictions.

\section{The mechanisms of constraint}

We are investigating the relationship between originalism in general (and Jack Balkin's framework originalism in particular) and the problem of constraint. Originalism solves the problem of constraint by adopting the fixation thesis and the constraint principle, but different forms of originalism vary outside of this core.

We can investigate the ways in which different forms of originalism tackle the problem of constraint by looking at their varying accounts of interpretation and construction. In the realm of interpretation, different originalist theories provide different accounts of the manner in which communicative content is fixed. In realm of construction, different originalist theories provide different versions of the constraint principle and different implementations of the idea of constraint. For our purposes, we can think of these different versions of originalism as providing different mechanisms of constraint.

\section{Constraint in interpretation}

Interpretation is the activity that recovers the communicative content of the constitutional text. Different versions of originalism offer different theories of communicative content. Of course, a full discussion of these theories would be quite lengthy, but we can offer a sketch of some of the different accounts. 
Consider first the distinction between versions of originalism that focus on the original intentions of the framers, the original understandings of the ratifiers, and the original public meaning of the text. All three versions accept the fixation thesis, varying only slightly as to the time of fixation. But these three versions of originalism differ more substantially in their account of the mechanism by which fixation occurs.

Consider first original intentions originalism. Let us adopt a very substantial simplification of intentionalism and assume that this version of originalism can be formulated as follows:

Original intentions originalism - the communicative content of the constitutional text is fixed by the communicative intentions of the framers at the time each provision was authored.

By way of contrast, we could formulate original understandings originalism in this way:

Original understandings originalism - the communicative content of constitutional text is fixed by the meaning grasped by participants in the ratification process at the time each provision was ratified.

And finally, public meaning originalism:

Original public meaning originalism-the communicative content of the constitutional text is fixed by the meaning of the constitutional grasped by competent speakers of American English at the time each provision was framed and ratified.

These three formulations involve substantially different accounts of the way that meaning is fixed, but these differences should not be exaggerated. In theory, it is possible that, with respect to a particular constitutional clause, the framers intended one meaning, the ratifiers grasped a second meaning, and the public understood the provision in yet a third way. In practice, framers (as competent speakers of English) are aware of the possibilities of miscommunication. This means they have good reason to employ words in their standard senses (conventional semantic meanings) and to hew close to standard forms of syntax and grammar. As a consequence, all three theories are likely to focus on the conventional semantic meaning of the constitutional text as the likely (or presumptive) meaning. We can call the conventional semantic meaning of the words and phrases as combined by syntax and grammar the "semantic content" of the text.

Almost all originalists are likely to accept the notion that at least part of the meaning of the constitutional text is provided by its semantic content. But originalists may differ with respect to the role that context plays in enhancing on enriching that semantic content. We are now discussing the aspect of meaning that philosophy of language and theoretical linguistics calls "pragmatics." For our purposes, let us call the acontextual meaning of a text its "semantic 
meaning": this idea roughly corresponds to what lawyers sometimes call "literal meaning." We can call the process by which context adds to semantic meaning "contextual enrichment." (In the philosophy of language and theoretical linguistics, the phrase "pragmatic enrichment" is used to name this concept, but for the purposes of legal theory the more familiar word "contextual" better communicates the idea.) The full communicative content of the text is the contextually enriched communicative content.

A full description of the various forms of contextual enrichment would require us to survey and categorize the various ways in which context adds to semantic content. One familiar example is the use of indexicals: "this," "here," "now," and pronouns like " $\mathrm{I}$ " or "you" are indexicals, their meaning depends on the context in which they are used. Acontextually, the sentence "I am writing this article" could refer to any article, but as used by me (Solum) on this occasion (in this essay in the ferusalem Review of Legal Studies) it refers to a particular person and a particular text. Another example of the role of context is the liquidation of ambiguity: the Constitution uses the word "Senate" and particular passages in the Constitution, if read acontextually, are ambiguous as between the Roman Senate, the Senate of University College, London, and the Senate of the USA. In context, the ambiguity disappears and it becomes clear that all of the uses of "Senate" in Article One of the US Constitution refer to the last of the three entities with the name "Senate." Additional forms of pragmatic enrichment are called implicature and impliciture: a text can mean more than it says. For example, the Ninth Amendment of the Constitution says, "The enumeration of certain rights in this constitution shall be construed to deny or disparage others retained by the people." This provision does state that there are any actual rights retained by the people; it is logically consistent with the nonexistence of such rights. But many careful readers of the Ninth Amendment believe that it makes no practical sense unless it is read as requiring the recognition of at least some unenumerated rights that are retained by the people: it would make no sense to prohibit the denying or disparaging of such rights if they did not exist.

Some originalists may believe that the communicative content of the Constitution should be limited to its semantic content. Because semantic content is relatively sparse, this limitation on content results in less constraint. The richer the communicative content, the more the constitution says, and therefore the more constraint it provides-relative to any particular articulation of the constraint principle. Ryan Williams provides an example of an originalist who argues for a limited role for contextual enrichment of semantic content. After recognizing the legitimacy of constitutional implication, Williams suggests the following criterion:

[I] $\mathrm{f}$ the implied content is not semantically encoded in the text, interpreters should inquire whether a reasonable member of the ratifying public at the time of enactment 
would have recognized the implied content as following obviously and noncontroversially from the choice of the particular language used in the provision and the relevant background context. ${ }^{20}$

Williams allows for contextual enrichment of semantic content, but imposes a significant limitation by excluding any actual contextual enrichment that is nonobvious or controversial.

Balkin does not take an explicit stand on contextual enrichment. Balkin is explicit that that by "original meaning" her refers to "the semantic content of the words in the clause." 21 To the extent that framework originalism limits original meaning to semantic content and excludes contextual enrichment, it dramatically reduces the constraint imposed by original meaning.

One more point about interpretation as a mechanism of constraint. Originalists and critics of originalism sometimes discuss "original expected applications." The phrase "original applications" or "original expected applications" seems to originate with Jack Balkin, ${ }^{22}$ but Mark Greenberg and Harry Litman articulated a similar distinction between "original meaning" and "original practices" in their important 1998 article, The Meaning of Original Meaning. ${ }^{23}$ The distinction is a simple one. The linguistic meaning of a text is one thing, and expectations about the application of that meaning to future cases are a different thing.

Balkin argues against the use of "original expected applications" as direct determinants of original meaning. ${ }^{24} \mathrm{His}$ argument is that expectations and meaning are conceptually distinct and hence that direct reliance on expected applications conflates application with meaning:

Originalists generally assume that if we do not apply the constitutional text in the way it was originally understood at the time of its adoption we are not following what the words mean and so will not be faithful to the Constitution as law. But they have tended to conflate two different ideas-the expected application of constitutional texts, which is not binding law, and the original meaning, which is. Indeed, many originalists who claim to be interested only in original meaning, like Justice Antonin Scalia, have encouraged this conflation of original meaning and original expected application in their practices of argument. ${ }^{25}$

Balkin may well be right to claim that some originalists conflate original meaning with expected applications, but to the extent that expectations are excluded, the degree of constraint is diminished.

\footnotetext{
${ }^{20}$ Ryan C. Williams, The Ninth Amendment as a Rule of Construction, 111 Colum. L. REv. 498, 544 (2011).

21 Balkin, supra note 1 at 13.

${ }^{22}$ See Jack M. Balkin, Abortion and Original Meaning, 24 Const. Comment. 291, 293 (2007) [hereinafter Abortion and Original Meaning].

${ }^{23}$ Mark D. Greenberg \& Harry Litman, The Meaning of Original Meaning, 86 Geo. L. J. 569 (1998).

${ }_{24}$ Jack M. Balkin, Original Meaning and Constitutional Redemption, 24 CoNst. Comment. 427, 446 (2007).

25 Balkin, supra note 22 at 292-93.
} 
The point of this section has been to provide an account of the various ways in which different originalist theories of interpretation (distinguished from construction) provide constraint. As a practical matter, most originalist theories converge on conventional semantic meaning to provide the semantic component of the communicative content of the constitutional text, but different versions of original differ with respect to contextual enrichment and the relevance of expectations about application. Balkin's position on expected applications is clear: he rejects application beliefs as constitutive of original meaning. His position on contextual enrichment is less clear; he may limit original meaning to semantic content. Assuming this limitation, it follows that Balkin's theory adopts a minimalist position (within the range of originalist options) with respect to the constraint imposed by the richness of the communicative content of the constitutional text.

\section{Constraint in construction}

Theories of interpretation provide constraint at the level of meaning or communicative content, but a theory of meaning alone cannot constraint constitutional practice. Meaning is one thing; legal effect is another. Even if the communicative content of the constitution were sufficiently rich so as to provide determinate answers to all constitutional questions, a further question would arise: does the communicative content bind judges, officials, and citizens when they act? This further question is answered by a theory of constitutional construction. One element of such a theory is an account of the relationship between communicative content and legal content or legal effect.

Even living constitutionalists are likely to admit that the original meaning of the constitutional text should play some role in constitutional practice. For example, one might believe that claims about original meaning constitute one legitimate form of constitutional argument, but that there are other forms, such as arguments from consensus social values or from political morality. Originalists characteristically endorse the stronger claim that is reflected in the constraint principle: the original meaning of the constitutional text should constraint judicial practice. Ordinarily, this means that the claim that a particular constitutional doctrine is inconsistent with original meaning would have trumping force-unless defeated, the fact of inconsistency with original meaning would be sufficient to establish that the doctrine is invalid. Similarly, the claim that a particular constitutional doctrine is required by original meaning would provide good and sufficient reason to adopt the doctrine.

But there can be different versions of the constraint principle. Constraint may be a matter of degree, but for ease of exposition consider the following formulations:

Strict construction-all of the legal content of constitutional doctrine must be derived from the communicative content of the constitutional text. 
Inclusive consistency-all of the legal content of constitutional doctrine must be consistent with the communicative content of the constitutional text, and all of the communicative content of the constitutional text must be included in the legal content of constitutional doctrine.

Strict Construction would require each and every rule of constitutional law to flow from the text in one of two ways: (i) the text must itself state rule, or (ii) the rule must be a logical implication of the text alone or of the text and nonlegal facts about the world. For an adherent of strict construction, all of the work is done by interpretation and factfinding: there is no construction zone. Inclusive consistency allows for the elaboration of legal content that goes beyond the communicative content of the text: for an adherent of inclusive consistency, there may be a constitutional construction zone where judges or other officials build out the constitutional framework (to use Balkin's metaphor).

\section{Three versions of originalist constraint}

Originalist theories vary in the degree to which they constrain constitutional practice. Theoretically, the degrees of constraint derive from the accounts of interpretation and construction contained in each version of originalism. We can now illustrate these differences by examining three different versions of originalism: (i) original methods originalism, (ii) originalist Thayerianism, and (iii) framework originalism.

\section{Original methods originalism: maximizing communicative content}

"Original methods originalism" is the name of view that the original meaning of the Constitution includes the methods of interpretation that the Framers, ratifiers, and/or public of the Founding era could, would, or should have expected to guide constitutional practice. This view is strongly associated with Michael Rappaport and John McGinnis. ${ }^{26}$ They write:

[T] he focus of originalism should be on how a reasonable person at the time of the Constitution's adoption would have understand its words and thought they should be interpreted. The Constitution's provisions were based on commonly accepted meanings and the interpretative rules of the time. Some of the provisions had clear meanings. Others may have seemed ambiguous, but the enactors would have believed that their future application would be based [on] the interpretive rules accepted at the time. Thus, their assessment of the meaning and the desirability of the Constitution would depend on the interpretive rules that they thought would apply. ${ }^{27}$

\footnotetext{
${ }^{26}$ Their view is briefly stated in John O. McGinnis \& Michael B. Rappaport, Original Interpretive Principles as the Core of Originalism, 24 Const. Cоммелт. 371 (2007) [hereinafter Original Interpretive Principles] and elaborated in Original Methods Originalism, supra note 11.

${ }^{27}$ McGinnis \& Rappaport, supra note 26 at 374.
} 
Notice that McGinnis and Rappaport's formulation of their idea does not embrace the distinction between interpretation and construction. Instead, there view is that the enrichment of the semantic content of the constitutional text by contextual information supplied by the original methods of constitutional interpretation provides sufficient communicative content that suffices to resolve constitutional controversies. If this is correct, then robust elaboration of legal content of constitutional doctrine is consistent with the strict construction version of the constraint principle.

\section{Originalist Thayerianism: minimizing judicial power}

Consider another possible version of originalism, which I will call "originalist Thayerianism"- a view that is artificially constructed for the purpose of exposition: the view is inspired in part by the constitutional theory of James Thayer, but it is not Thayer's own view. ${ }^{28}$ This view is defined by two principles of constitutional construction:

Modified literalism-the legal content of judicially enforceable constitutional doctrine shall be equivalent to the semantic content of constitutional text enhanced only by the obvious and uncontested contextual enrichment.

fudicial restraint-Courts may only enforce the legal content derived from the constitutional text by the principle of modified literalism; in cases presenting constitutional question not resolved by such content, the judicial branch shall defer to the constitutional constructions of the political branches or the states.

Originalist Thayerianism provides a very high degree of constraint for judges, but allows other officials substantial latitude in constitutional interpretation and construction. It achieves this constraint in two ways. First, it artificially restricts contextual enrichment of the literal meaning (semantic content) of the text by adopting the principle of modified literalism. Second, it requires judges to defer to the political branches when constitutional meaning is uncertain: when the modified literal meaning is ambiguous, vague, gappy, or contradictory, judges must defer to the constitutional constructions of the Executive, Congress, or the States.

\section{Framework originalism}

This brings us to Jack Balkin's theory, framework originalism. Balkin does not explicitly address the question of contextual enrichment, but what he does say suggests that constitutional interpretation should focus on the semantic content of the constitutional text. It also seems clear that Balkin rejects the claim that contextual enrichment provides sufficient communicative content to provide substantial constitutional determinacy. Thus, we can assume that Balkin believes in a substantial construction zone: the framework settles some questions,

${ }^{28}$ James B. Thayer, The Orign and Scope of the American Doctrine of Constitumonal Law (1893). 
but many others will require judges and officials to create legal content to resolve irreducible ambiguities, vagueness, gaps, and contradictions.

In particular, Balkin believes that the constitutional text contains different types of semantic content, corresponding to the familiar typology of legal rules, standards and principles:

Fidelity to the Constitution requires fidelity to the original meaning of the text, and to the choice of rules, principles, and standards in the text. It requires us to be faithful both to the principles that are stated in the text and those that we understand to be presupposed by the text or underlie the text, and it requires us to build out constitutional constructions that best apply the text and its associated rules, standards, and principles to our current circumstances. We might call this approach to constitutional interpretation 'the method of text, rule, standard, and principle;' however, as convenient shorthand, I call it the method of text and principle. ${ }^{29}$

Principles are particularly important, precisely because they are not rules. Rather, these are the "open ended" or "open textured" provisions of the Constitution, "for example, the First Amendment's guarantee of freedom of speech and the Fourteenth Amendment's guarantee of equal protection of the laws." ${ }^{30}$ Once we are in the realm of constitutional principle, we are in the construction zone. It just is the nature of principles that they are not rules; they guide the process of construction but they do not determine its outcome.

So Balkin does not believe that constitutional construction is unconstrained. The method of text and principle is a modified version of Phillip Bobbitt's view that the legal content of constitutional doctrine is constructed by a complex practice of argument that incorporates "text, history, structure, precedent, ethos, and consequences." 31 Unlike Bobbitt, whose account of the modalities of constitutional argument does not provide a hierarchy or lexical ordering, Balkin's framework originalism privileges arguments from text: "Interpretations and constructions may not contradict original meaning; therefore once we know the original meaning of the text, it trumps any other form of argument."32

We can now step back and compare framework originalism with original methods originalism and originalist Thayerianism. Framework originalism's understanding of original meaning is thin or sparse as compared to original meaning originalism: Balkin believes that key constitutional provisions provide general and abstract principles and hence that their communicative content underdetermines the content of constitutional doctrine. Original methods

\footnotetext{
${ }^{29}$ Jack Balkin, Nine Perspectives on Living Originalism, 2012 U. IL. L. Rev. 815, 817.

30 Id.

${ }^{31}$ See Id. at 868; Balkin, supra note 1 at $341 \mathrm{n}$. 2 (attributing the tools to Bobbitt); see also Phus BoBBITT, Constitutional Interpretation (1993); Phul Bobbitt, Constrtutional Fate: Theory of the Constitution (1982).

${ }^{32}$ See Balkin, supra note 1 at 341-42 n. 2.
} 
originalism holds that the sparse semantic content of the text can be enriched contextually by the original methods of constitutional interpretation, and hence a much richer (and perhaps determinate) content for provisions like the freedom of speech and equal protection. In this regard, framework originalism actually resembles originalist Thayerianism on the interpretation side of the ledger, but when it comes to constitutional construction, framework originalism does not adopt the Thayerian principle of judicial restraint. Framework originalism licenses robust judicial construction of constitutional doctrines with respect to at least some constitutional provisions. Both framework originalism and originalist Thayerianism require extensive construction, but Thayerianism endorses only one principle of judicial construction-the self-abnegating principle of judicial restraint that requires courts to respect constructions by the political branches of the federal government and the states.

If we compare framework originalism to other members of the originalist family, then the degree of constraint appears minimal. Balkin's theory allows for a relatively large construction zone-although the constitutional framework itself may determine a variety of important constitutional questions, especially on matters of structure where the constitutional text provides rules (rather than standards or principles). But if we compare framework originalism to living constitutionalism, then the comparative degree of constraint looks a bit different. At least some versions of living constitutionalism reject the constraint principle. Bobbitt's theory, for example, allows for the possibility that constitutional arguments based on the nomos (or dominant normative framework) would outweigh or defeat arguments based on the text and its history. When framework originalism is compared to theories like Bobbitt's, the degree of constraint seems relatively high.

\section{Conclusion: how much constraint should originalists want?}

We are now is a position to ask the normative question, does framework originalism provide sufficient constraint? Or should originalists demand the greater degree of constraint provided by original methods originalism or originalist Thayerianism? These are complex questions; answers are beyond the scope of this essay. Nonetheless, we can do something about the considerations that bear on these questions. From the point of view of originalist theory, the question of constraint has two dimensions. In the realm of interpretation, the question of constraint is simply a matter of fact. Relative to our best understandings in theoretical linguistics and the philosophy of language, there is a fact of the matter about the communicative content of the constitutional text. If the communicative content is rich, then it is capable of providing more constraint-relative to whatever version of the constraint principle applies. But if the communicative content is sparse, then construction will be 
required-when meaning runs out, something else must do the work for constitutional practice. How rich is the communicative content of the constitutional text? That is a very complex question!

Theories of constitutional construction guide constitutional practice. Such theories require normative justification of some kind. From the perspective of originalist constitutional theory, theories of constitutional construction are answerable to the underlying justifications for originalism. For example, some originalists rely on popular sovereignty theory: the original meaning of the constitution has normative legitimacy because the Constitution was adopted by "We the People." For a popular sovereignty theorist, the justification for constraint is the democratic nature of constitutional politics. Other originalists rely on rule of law values as the justification for the constraint principle; for them, the question is what version of the constraint principle best achieves the rule of law values of predictability, certainty, and stability.

In addition to the normative justifications for originalism itself, institutional concerns may be relevant. One such concern relates to the institutional capacities and trustworthiness of courts and judges. To the extent that some originalists believe that unconstrained judging is dangerous or that courts lack the institutional capacity to make wise decisions in the process of constitutional construction, these originalists will favor versions of the constraint principle that minimize the size of the construction zone.

Jack Balkin's theory, framework originalism, results in a relatively low degree of constraint (compared to other forms of originalism). His theory of interpretation yields relatively sparse communicative content; his theory of construction requires fidelity to that content, but allows for relatively robust practices of construction by both judges and political officials. But compared to some forms of living constitutionalism, framework originalism looks very constrained-judges and officials are required to acknowledge the trumping force of original meaning. For this reason, framework originalism will appeal to those who seek a middle ground. For them, Balkin's version of originalism may be "just right." 